4. Recommendation $\operatorname{Rec}(2001) 9$ of the Committee of Ministers to member states on alternatives to litigation between administrative authorities and private parties: Recommendation, adopted by the Committee of Ministers on 5 September 2001 / Committee of Ministers. URL: https://rm.coe.int/16805e2b59 (дата звернення: 27.10.2020).

5. Проект Закону про медіацію: Проект Закону від 19.05.2020 № 3504 / Верховна Рада України. URL: http://w1.c1.rada.gov.ua/ pls/zweb2/webproc34?id=\&pf3511=68877\&pf35401=527488

(дата звернення: 27.10.2020).

6. Про Державний бюджет України на 2010 рік: Закон України від 27.04.2010 № 2154-VI / Верховна Рада Украӥни. URL: https://zakon.rada.gov.ua/laws/show/2154-17\#Text (дата звернення: 27.10.2020).

7. Берт Маан, Ремко ван Рi, Сергєєва А., Сергєєва С., Романадзе Л., Родченко B. Gap-Аналіз впровадження інституту медіації в Україні. Проект СС Право-Justice. 2020. 93 с.

8. Melinda Jone. Tax Dispute Systems Design in the Context of the Australian Taxation Office's Reinvention Program. Austaxpolicy, the blog of the Tax and Transfer Policy Institute at the Crawford School of Public Policy, The ANU. URL: https://www.austaxpolicy.com/tax-dispute-systemsdesign-context-australian-taxation-offices-reinvention-program/ (дата звернення: 27.10.2020).

DOI https://doi.org/10.30525/978-9934-588-92-1-70

\title{
FINANCIAL SERVICES IN UKRAINE: CONCEPT, ESSENSE AND CLASSIFICATION
}

\author{
Soloshkina I. V. \\ Doctor of Law, \\ Associate Professor at the Department of State and Legal Disciplines \\ V. N. Karazin Kharkiv National University \\ Kharkiv, Ukraine
}

The financial services market is a voluminous and multidimensional phenomenon where financial resources turn into capital investments. Various points of view are being expressed in the scientific literature to determine the financial services market. Some stating that it is a certain 
economic space for the sale and purchase of financial services. Others that it includes the activities of state and financial institutions to meet financial needs.

It should also be emphasized that the legislator divides all participants in the financial services markets into four groups:

- persons who, in accordance with the law, have the right to provide financial services in Ukraine;

- persons engaged in the provision of intermediary services in the financial services markets;

- an association of financial institutions included in the register of selfregulatory organizations;

- consumers of financial services.

At the same time, the legislator also points to other participants in the financial services markets, which may be determined by regulatory acts on the regulation of individual financial services markets.

The reason for this situation in Ukraine is the imperfection of the current legislation and the modern mechanism of state regulation of the provision of financial services. The gaps in the current legislation allow some individuals the opportunities for exploitation of the financial institutions for their own enrichment at the expense of consumers.

The official definition of financial services is regulated by the Law of Ukraine "On Financial Services and State Regulation of Financial Services Markets". According to the paragraph 5 of Part 1 of Art. 1 of the said Law, financial services are operations with financial assets that are carried out in the interests of the third parties at their own expense or at the expense of these persons, and in cases provided for by the legislation, at the expense of financial assets attracted from other persons for the purpose of making a profit or maintaining the real value of financial assets. The legislator avoids a clear definition of the concept of "financial assets", and limits it by the list in clause 4, part 1, article 1 of the same Law. The list includes the following objects: funds, securities, debt obligations and the right to claim debt that are not related to securities [1].

Referring to the regulatory framework that contains the definition of objects included in the list of "financial assets", we could concentrate on the following issues listed below. The first concept of «funds» is presented in the Law of Ukraine «On Banks and Banking Activities» as money in national or foreign currency or its equivalent [2]. The term "funds" in this case is related to any funds that are in legal circulation in Ukraine. However, instead of the definition of "funds" in the concept of "financial assets", it would be necessary to indicate directly in the text of p. 4 part 1 of art. 1 of the Law of Ukraine "On Financial Services and State Regulation of 
Financial Services Markets" - "cash in national or foreign currency". This amendment will make the Law to define clearly the essence of this concept.

The second concept of "securities" is addressed in three regulatory acts: in part 1 of art. 194 of the Civil Code of Ukraine [3], Part 1 of Art. 163 of the Economic Code of Ukraine [4]/ According to these laws, a security is a document of the established form with relevant details certifying a monetary or other property right that defines the relationship between the person who placed it (issued) and the owner and provides for the fulfillment of obligations under the terms of its placement, as well as the possibility of transfer rights arising from this document to other persons.

The third concept of "debt obligation" is defined in the Budget Code of Ukraine. It is interpreted as the obligations of the borrower to the creditor on the loan, resulting from the issuance and placement of debt securities and / or concluding credit agreements [5].

Current legislation does not contain the fourth notion of "the right to claim debt". However, the legislator broadly uses the indicated term when regulating a factoring contract. Under the factoring contract (financing under the assignment of a monetary claim), one party (factor) transfers or undertakes to transfer the funds to the second party for a fee. In return, the client transfers the right or agrees to transfer the right to claim debt from the third party (debtor) to the factor as indicated in part 1, article 1077 of the Civil Code of Ukraine [3].

Therefore it is important to note that the derivation of the term "financial assets" by using the technique of defining one term through another is unsuccessful since not all the categories in the list of "securities, debt obligations and the right to claim debts that are not related to securities." have legal definitions.

In the study of the concept of «financial assets» it would be impossible to circumvent the notion of «financial instruments» associated with it. The legislator in the definition of this category in the conceptual apparatus p. 20 Part 1 of Art. 1 of the Law of Ukraine «On Securities and the Stock Market» went the same way as in determining financial assets. Financial instruments are securities, futures contracts (futures), interest futures contracts (forwards), futures contracts for exchange (as of a certain future date) in the case of price dependence on interest rate, exchange rate or stock index, options giving the right to the purchase or sale of any of these financial instruments, including those involving a monetary form of payment (exchange rate and interest options). Based on this concept, we can conclude that financial instruments are certain documents - securities and special agreements. Other documents that partially support this definition are subordinate regulations that implement international standards in the national legislation on accounting. 
According to this criterion, the following types of financial services can be distinguished: 1) issuance of payment documents, payment cards, travelers checks and / or their maintenance. The general principles of functioning of payment systems and settlement systems in Ukraine are determined by the Law of Ukraine "On Payment Systems and Transfer of Funds in Ukraine" dated April 5, 2001. Thus, in accordance with Art. 1 of this legal act, the settlement document is defined as a document for transfer of funds to be used to initiate the transfer from the payer to the payee's account. In turn, a payment card is an electronic means of payment in the form of a plastic or other type of card issued in accordance with the current legislation that is used to initiate a transfer of funds from the payer's account or from the corresponding bank account to pay for the cost of goods and services, transfer funds from their accounts to the accounts of other persons, to receive funds in cash at the bank's cash desks, through automatic teller machines, as well as to carry out other operations stipulated by the relevant agreement. Settlement check is a paper settlement document containing the unconditional order of the payer to the bank that services it to transfer the amount of funds to the beneficiary specified in it 2) clearing is a mechanism that includes collecting, sorting and offsetting reciprocal claims of participants in the payment systems, and also calculation on each of them the total balance for a certain period of time between total amounts of transactions; 3) other forms of payment support including: - Quiring technological information services for settlements on transactions made using electronic means of payment in the payment system; - Issuing electronic means of payment - conducting operations to issue electronic payment means of a certain payment system; - Processing - an activity that includes the execution of operations with payment instruments for the authorization, monitoring, collection, processing and storage of information, as well as the provision of the processed information to the participants of the settlement and the settlement bank for carrying out mutual settlements in the payment system; - Settlement and cash services - services provided by a bank on the basis of a relevant agreement related to transfer of funds from the account (to the account) of the relevant person, disbursement of funds in cash, as well as other operations stipulated by the agreements 6 .

In this paper I addressed the concept, the essence of financial services based on the scientific work of Ukrainian and foreign scientists. It is being determined that the subjects of financial services are: business entities with different legal status granted the right to carry out activities to provide financial services in Ukraine; consumers of said services; bodies regulating and controlling the provision of financial services in Ukraine. It is also being determined that the classification of financial services is the distribution of 
their types to certain groups in accordance with the type and scope of activities of financial institutions.

\section{References:}

1. "On Financial Services and State Regulation of Financial Services Markets” :Law of Ukraine12.07.2001 № 2664-III // http://zakon2.rada.gov.ua/laws/

2. «On Banks and Banking Activities» Law of Ukraine: 07.12.2000, № 2121-III // http://zakon2.rada.gov.ua/laws/

3. "Civil Code of Ukraine Law of Ukraine": 16.01.2003 № 435-IV// http://zakon2.rada.gov.ua/laws/

4. "Economic Code of Ukraine Law of Ukraine": 16.01.2003 № 436-IV // http://zakon2.rada.gov.ua/laws/

5. "Budget Code of Ukraine":Law of Ukraine 24.12.2010 // http://zakon2.rada.gov.ua/laws/

6. "On Payment Systems and Transfer of Funds in Ukraine": Law of Ukraine 05.06.2001 // // http://zakon2.rada.gov.ua/laws/

DOI https://doi.org/10.30525/978-9934-588-92-1-71

\section{СОЦІАЛЬНА ІНЖЕНЕРІЯ ТА УПРАВЛІННЯ РИЗИКАМИ ЛЕГАЛІЗАЦЇ̈ КОШТІВ}

\section{Сосенко В. М.}

аспірант кафедри господарського та адміністративного права Національного технічного університету Украӥни «Київський політехнічний інститут імені Ігоря Сікорського» м. Київ, Україна

Дистанційне надання фінансових послуг на сьогодні $€$ вкрай актуальним, що зумовлено як розвитком технологій так і соціальним дистанціюванням через пандемію. 3 розвитком інтернет-технологій прямо пропорційно збільшуються і види кіберзлочинів серед яких соціальна інженерія [1, с. 214], а використання новітніх технологій для відмивання коштів/фінансування тероризму має високий ризик через використання дистанційних послуг [1, с. 233]. Інформаційно-телекомунікаційні та комп'ютерні технології досягли рівня, що спрощують процеси отримання ідентифікаційної інформації та дозволяють верифікувати особу, водночас із тим, обмежуючи фізичне сприйняття 288 